\title{
PENGARUH PERMAINAN TRADISIONAL PETAK UMPET TERHADAP PENYESUAIAN SOSIAL ANAK USIA SEKOLAH DASAR
}

\author{
Valentina Mbadhi ${ }^{1}$, Maria Finsensia Ansel ${ }^{2}$, Agustina Pali $^{3}$ \\ Universitas Flores ${ }^{1,2,3}$ \\ mariafinsensiaansel@gmail.com ${ }^{1}$
}

\begin{abstract}
ABSTRAK
Tujuan penelitian adalah untuk mengetahui pengaruh permainan tradisional petak umpet terhadap penyesuaian sosial anak usia sekolah dasar di RT 01 dan 02 Kelurahan Rewarangga Selatan. Metode penelitian yang digunakan yaitu penelitian kuantitatif. Sampel dalam penelitian anak-anak usia sekolah dasar kelas 4, 5 dan 6 yang berjumlah 57 orang anak dengan teknik pengambilan sampel dengan cara probability sampling yang meliputi teknik simple random sampling. Instrumen yang digunakan adalah angket. Data dianalisis dengan teknik statistik deskriptif, uji prasyarat analisis yang terdiri dari uji normalitas dan linearitas dan uji regresi. Hasil penelitian, hasil persamaan regresi $\mathrm{Y}=49.739+0,498 X$, nilai signifikansi yang diperoleh sebesar 0,019 lebih kecil dari probabilitas 0,05 , nilai $\mathrm{t}$ hitung sebesar 2,444 lebih besar t tabel sebesar 2,026 dan nilai $R$ Square sebesar 0,139 atau $13,9 \%$ sedangkan sisanya sebesar $86,1 \%$ dipengaruhi oleh variabel lain. Simpulan, ada pengaruh yang positif signifikan permainan tradisional petak umpet terhadap penyesuaian sosial anak usia sekolah dasar
\end{abstract}

Kata Kunci: Permainan Tradisional, Petak Umpet, Penyesuaian Sosial, Anak Usia Sekolah Dasar

\begin{abstract}
The aim of the research was to find out the influence of traditional game hideand-seek to the social adaptation of elementary students in RT 01 and 02 South Rewarangga. The method of the research was quantitative research. The sample was the elementary students of graden 4, 5 and 6 consist of 57 students through probability sampling whichc included in simple random sampling. The instruments used were questionnaire. The data were analyzed by using descriptive statistical technique, try out test including normality, linearity and regression test. The result included regression result $Y=49.739+0,498 X$, the significant score was 0,019 smaller than probability score 0,05, $t$ obtain was 2,444 higher than the t table 2,026 and $R$ Square was 0,139 or 13,9\% whereas the rest was $86,1 \%$ influenced by other variables. In conclusion, there was a significant influence of the application of traditional game hide-and-seek towward elementary students social adaptation.
\end{abstract}

Keywords: Traditional Games, Hide and Seek, Social Adaptation, Elementary School Students 


\section{PENDAHULUAN}

Hakikat manusia yang berhubungan dan membutuhkan orang lain demi kelangsungan hidupnya menegaskan bahwa manusia merupakan makluk sosial. Sebagai makluk sosial, manusia mulai dari bayi, anak-anak, dewasa dan orangtua perlu berinteraksi dan bersosialisasi dalam kehidupannya. Anak-anak juga dalam kehidupannya tidak terlepas dari teman-teman sebayanya dan dewasa lainnya seperti keluarga, sekolah dan masyarakat. Anak-anak akan melakukan berbagai kegiatan baik di rumah, sekolah maupun masyarakat khususnya pada lingkungan tempat tinggal anak. Kegiatan-kegiatan yang dilakukan anak di antaranya bermain dan belajar khususnya pada anak usia sekolah dasar.

Usia sekolah dasar merupakan usia 6-12 tahun di mana anak memperoleh dasar-dasar pengetahuan untuk keberhasilan penyesuaian diri selanjutnya. Sehingga pada usia ini anak harus banyak bersosialisasi dan beriteraksi dengan teman sebayanya dan orang-orang dewasa. Anak usia sekolah dasar merupakan tahap awal anak sekolah dan belajar. Pada saat anak jenuh dalam belajar, maka anak menghentikan sejenak kegiatan belajar dan cara menghilangkan kejenuhan terhadap belajar adalah bermain.

Bermain merupakan sebuah kegiatan yang sangat akrab dengan kehidupan anak-anak, sehingga permainan tidak pernah lepas dari kehidupan anak usia sekolah dasar. Setiap anak akan melakukan permainan karena dengan bermain anak-anak melakukan penyesuaian sosial. Hal ini didukung oleh Tedjasaputra dalam studinya yang menegaskan bahwa kegiatan bermain dengan teman-teman sebayanya ditandai dengan adanya interaksi dengan teman-teman lain, sehingga anak mampu bekerja sama dalam permainan. Dengan demikian anak-anak akan mengurangi perilaku egosentrisnya dan secara bertahap dapat berkembang menjadi makhluk sosial yang bergaul dan menyesuaikan diri dengan lingkungan sosialnya. Semakin dipertegas oleh Mulyadi, yang menambahkan sosialisasi dapat dipupuk melalui kesempatan bermain bersama teman-teman sebayanya. Lebih lanjut Raharjini menambahkan bentuk permainan juga mempengaruhi proses sosialisasi anak. Bentuk permainan menurut Suyami, secara umum dibedakan menjadi dua yaitu permainan tradisional dan permainan modern. (Wahyuni, 2009).

Permainan tradisional sebagai sarana untuk memperkenalkan anak-anak terhadap nilai budaya dan norma sosial yang dibutuhkan dalam mengadakan hubungan atau kontak sosial dalam masyarakat. Bentuk bentuk pemainan lebih mengarah ke dalam kelompok dimana anak membutuhkan teman-temannya dalam melakukan permainan sehingga penyesuaian sosial anak dengan teman-temannya akan terlihat dengan jelas. Macam-macam permainan tradisional, seperti tarik tambang, tali merdeka (lompat tali), bola kasti, segengge/bentengan (gobak sodor), dokan, kelereng, layang-layang, boi, ogo, peneke (petak umpet) dan lainlain dan setiap daerah mempunyai sebutan yang khas untuk setiap jenis permainan tradisional. Sementara permainan modern sebagian besar dimainkan secara individual. Sekalipun dimainkan oleh dua anak, penyesuaian sosial anak dengan temannya tidak terlalu terlihat. Permainan modern antara lain permainan yang terdapat dalam play station, pemainan yang bisa di-download melalui internet maupun di-instal melalui compact disc (CD), handphone, laptop dan komputer.

Bentuk permainan yang menguntungkan untuk anak adalah permainan tradisional karena dapat mengembangkan interaksi sosial yang nantinya akan 
terlihat pada penyesuaian sosial anak. Lebih lanjut, Mulyani, Novi. (2016), mengemukakan bahwa perkembangan sosial anak dapat pula dilihat dari kemampuannya bersosialisasi dan berinteraksi dengan teman sebayanya. Permainan tradisional membawa pengaruh yang cukup besar bagi penyesuian sosial anak. Hal ini dapat saja terwujud melalui media permainan tradisional yang dapat mengembangkan kemampuan sosialnya. Salah satu permainan tradisional yang diharapkan mampu meningkatkan penyesuaian sosial anak adalah petak umpet(bermain sembunyi) yang dalam bahasa ende dikenal dengan nama permainan peneke.

Petak umpet atau dalam bahasa Inggris disebut hide and seek adalah salah satu permainan tradisonal anak-anak yang sudah sangat terkenal. Selain di Indonesia, permainan ini juga sangat digemari oleh anak- anak di luar negeri (Agustin, 2017). Menurut Achroni (Agustin, 2017) mengatakan bahwa "permainan petak umpet merupakan permainan yang menyenangkan bagi anak yang dapat dimainkan dengan cara mencari teman-temannya yang bersembunyi". Selanjutnya Wahyuni (2009) mendefinisikan "petak umpet adalah sejenis permainan cari dan sembunyi yang bisa dimainkan minimal 2 oang yang umumnya berada diluar ruang. Dalam permainan, ada dua peran, yaitu si kucing dan yang bersembunyi. Si kucing ini berperan mencari teman-temannya yang bersembunyi. Permainan selesai setelah semua teman ditemukan. Dan yang pertama ditemukan yang menjadi kucing berikutnya". Maka dapat disimpulkan bahwa permainan tradisional petak umpet adalah permainan yang sudah ada sejak jaman dahulu yang merupakan warisan turun temurun dari satu generasi ke generasi selanjutnya dan sering dimainkan oleh anak-anak untuk memperoleh kesenangan yang dimainkan oleh dua atau lebih orang anak tidak memerlukan alat dalam permainannya hanya memanfaatkan lingkungan di sekitarnya untuk bersembunyi.

Banyak manfaat dalam permainan petak umpet diantaranya mengembangkan kemampuan sosial emosional anak dalam hal melatih anak untuk bisa dan mau bermain bersama dengan orang lain, melatih kerjasama anak dalam hal bersedia untuk membantu sesama teman, serta dapat memberikan kegembiraan pada anak. Manfaat pemainan tradisional petak umpet didalamnya juga terdapat proses sosialisasi. Proses sosialisasi ini tidak dapat terpisah dari penyesuian sosial anak dimana anak yang tidak mampu melakukan penyesuian sosial dengan baik biasanya menyendiri, tidak bisa bergaul dengan temantemannya, dan merasa kaku. Anak yang bisa melakukan penyesuian sosial mempunyai dampak positif, yaitu dapat membangun sikap sosial yang menyenangkan, seperti kesediaan untuk membantu orang lain (Hurlock, 2002).

Hasil observasi terhadap anak-anak di RT 01 dan RT 02 Kelurahan Rewarangga Selatan Kecamatan Ende Timur diketahui bahwa banyak anak-anak yang sudah jarang melakukan permainan yang bersifat tradisional salah satu yang penulis amati adalah banyak anak yang jarang melakukan permainan petak umpet. Hal ini dibuktikan dengan hasil wawancara kepada beberapa anak diketahui bahwa sebagian anak mengakui bahwa mereka masih melakukan permainan petak umpet dan merasa sangat senang ketika melakukan permainan ini tetapi ada sebagian anak yang mengatakan mereka jarang bermain dengan teman-temannya di rumah, lebih banyak menghabiskan waktu didalam rumah dan bermain game di handphone, laptop, computer dan playstation. 
Kenyataan yang terjadi ini menyatakan bahwa ada anak yang mengakui bahwa mereka masih melakukan permainan tradisional petak umpet walaupun tidak semua anak memainkannya, tetapi masih ada anak yang melakukan permainan petak umpet dan pada saat anak bermain anak akan melakukan sosialisasi dengan teman-temannya atau orang lain di sekitarnya yang berkaitan dengan penyesuaian sosial anak. Untuk itu penulis tertarik untuk mengkaji salah satu permainan tradisonal yaitu permainan petak umpet untuk mendalami pengaruhnya pada penyesuaian sosial anak.

Rumusan masalah dalam penelitian ini adalah "apakah ada pengaruh permainan tradisional petak umpet terhadap penyesuian sosial anak di Rt. 01 dan Rt. 02 Kelurahan Rewarangga Selatan Kecamatan Ende Timur Kabupaten Ende?".Adapun tujuan dalam penelitian ini adalah untuk mengetahui pengaruh permainan tradisional petak umpet terhadap penyesuian sosial anak usia sekolah dasar di Rt. 01 dan Rt. 02 Kelurahan Rewarangga Selatan Kecamatan Ende Timur Kabupaten Ende.

\section{METODE PENELITIAN}

Pendekatan penelitian yang digunakan dalam penelitian ini adalah pendekatan kuantitatif. Dalam penelitian ini, permainan tradisional petak umpet merupakan variabel bebas (dependent variable), dinyatakan dalam X. Selanjutnya, penyesuaian sosial anak merupakan variabel terikat (independent variable), dinyatakan dalam Y.

Populasi dalam penelitian ini adalah seluruh anak usia sekolah dasar di wilayah RT 01 dan RT 02 Kelurahan Rewarangga Selatan Kecamatan Ende Timur kabupaten Ende, yang berjumlah 70 orang dengan teknik pengambilan sampel dengan cara probability sampling yang meliputi teknik simple random sampling karena pengambilan anggota sampel dari populasi dilakukan secara acak tanpa memperhatikan strata yang ada dalam populasi itu (Sugiyono, 2010). Maka dalam penelitian ini yang menjadi sampel penelitian adalah anak usia sekolah dasar kelas 4, kelas 5 dan kelas 6 di RT 01 dan RT 02 Kelurahan Rewarangga Selatan Kecamatan Ende Timur Kabupaten Ende yang berjumlah 39 orang.

Metode pengumpulan data dengan menggunakan angket atau kuesioner yaitu angket tentang permainan tradisional petak umpet dan penyesuaian sosial anak. Penetapan skor instrumen menggunakan empat alternatif jawaban yaitu selalu, sering, kadang-kadang dan tidak pernah baik untuk pernyataan favorable dan unfavorable. Untuk pernyataan favorable jika memilih alternatif jawaban selalu diberi skor 4, sering diberi skor 3, kadang-kadang diberi skor 2, dan tidak pernah diberi skor 1. Sebaliknya untuk pernyataan unfavorable jika memilih selalu diberi skor 1, sering diberi skor 2, kadang-kadang diberi skor 3, dan tidak pernah diberi skor 4 .

Hasil perhitungan validitas dari 30 item pernyataan angket permainan tradisional petak umpet semua item dinyatakan valid dengan kisaran item validnya sebesar 0,391 sampai dengan 0,759 dan nilai reliabilitas sebesar 0,912 yang artinya sangat reliabel dan dapat digunakan sebagai instrumen dalam penelitian ini. Sementara angket penyesuaian sosial anak usia sekolah dasar dari 30 item pernyataan ditemukan semua item pernyataan dinyatakan valid dengan nilai validitas angket berkisar dari nilai 0,366 sampai dengan 0,705 dan nilai 
reliabilitas sebesar 0,897 artinya sangat reliabel dan dapat digunakan sebagai instrumen dalam penelitian ini.

Metode analisis data yang dilakukan melalui analisis statistik deskriptif, uji prasayarat analisis yang meliputi uji normalitas dan uji linieritas, uji hipotesis dengan menggunakan teknik analisis regresi sederhana. Analysis data akan dilakukan menggunakan program SPSS versi 16.

\section{Hasil Penelitian}

Berikut ini tabel distribusi frekuensi variabel permainan tradisional petak umpet.

Tabel 2

Tabel Distribusi Frekuensi Variabel Permainan Tradisional Petak Umpet

\begin{tabular}{cccc}
\hline No & Kelas Interval & Frekuensi & Persentase \\
\hline 1 & $83-86$ & 3 & $7,69 \%$ \\
\hline 2 & $87-89$ & 3 & $7,69 \%$ \\
\hline 3 & $90-92$ & 9 & $23,08 \%$ \\
\hline 4 & $93-95$ & 15 & $38,46 \%$ \\
\hline 5 & $96-98$ & 7 & $17,95 \%$ \\
\hline 6 & $99-101$ & 2 & $5,13 \%$ \\
\hline & Jumlah & $\mathbf{3 9}$ & $\mathbf{1 0 0 \%}$
\end{tabular}

Diketahui bahwa responden yang memilih kelas interval 93-95 yaitu sebanyak 15 anak, selanjutnya interval kelas 90-92 sebanyak 9 anak, interval 9698 sebanyak 7 anak, interval 83-86 dan interval 87-89 sebanyak 3 anak, dan rentang 99-101 sebanyak 2 anak. Sementara hasil perhitungan tabel distribusi frekuensi varibel penyesuaian sosial anak berikut ini:

Tabel 3

Tabel Distribusi Frekuensi Penyesuaian Sosial Anak

\begin{tabular}{|c|c|c|c|}
\hline No & Kelas Interval & Frekuensi & Persentase \\
\hline 1 & $77-82$ & 4 & $10,26 \%$ \\
\hline 2 & $83-88$ & 4 & $10,26 \%$ \\
\hline 3 & $89-94$ & 12 & $30,76 \%$ \\
\hline 4 & $95-100$ & 8 & $20,51 \%$ \\
\hline 5 & $101-106$ & 7 & $17,95 \%$ \\
\hline 6 & $107-113$ & 4 & $10,26 \%$ \\
\hline & Jumlah & 39 & $100 \%$ \\
\hline
\end{tabular}

Tabel distribusi frekuensi variabel penyesuaian sosial anak di atas, diketahui bahwa kelas interval tertinggi yaitu rentang 89-94 sebanyak 12 anak, selanjutnya kelas interval 95-100 sebanyak 8 anak, kelas interval 101-106 sebanya 7 anak, sementara kelas interval 77-82, 83-88, dan 107-113 masing-masing sebanyak 4 anak.Selanjutnya dibuatkan kategorisasi penilaian untuk variabel permainan tradisional petak umpet dan penyesuaian sosial anak yaitu sebagai berikut: 
Tabel 4

Kategorisasi Penilaian Variabel Permaianan Tradisional Petak Umpet

\begin{tabular}{lccl}
\hline \multicolumn{1}{c}{ Skor } & Frekuensi & Persentase (\%) & Kategori \\
\hline $\mathrm{X}<75$ & 0 & $0 \%$ & Rendah \\
\hline $75 \leq \mathrm{X}<105$ & 39 & $100 \%$ & Sedang \\
\hline $105 \leq \mathrm{X}$ & 0 & $0 \%$ & Tinggi \\
\hline Jumlah & $\mathbf{3 9}$ & $\mathbf{1 0 0 \%}$ & \\
\hline
\end{tabular}

Tabel kategorisasi penilaian permainan tradisional petak umpet di atas, diketahui bahwa semua anak sebanyak 39 orang anak berada pada kategori sedang dengan persentase $100 \%$. Sehingga secara keseluruhan dapat disimpulkan bahwa semua anak melakukan permainan tradisional petak umpet. Sedangkan untuk penyesuaian sosial anak dapat dilihat dalam tabel berikut ini:

Tabel 5

Katogorisasi Penilaian Penyesuaian Sosial Anak

\begin{tabular}{cccl}
\hline \multicolumn{1}{c}{ Skor } & Frekuensi & Persentase (\%) & Kategori \\
\hline $\mathrm{X}<75$ & 0 & $0 \%$ & Rendah \\
\hline $75 \leq \mathrm{X}<105$ & 38 & $97,44 \%$ & Sedang \\
\hline $105 \leq \mathrm{X}$ & 1 & $2,56 \%$ & Tinggi \\
\hline Jumlah & $\mathbf{3 9}$ & $\mathbf{1 0 0}$ & \\
\hline
\end{tabular}

Tabel kategorisasi penyesuian sosial anak dapat diketahui bahwa tidak ada anak yang berada pada kategori penyesuian sosial rendah, 38 orang anak berada pada kategori penyesuaian sosial sedang dengan persentase sebesar 97,44\%, dan 1 orang anak berada pada kategori penyesuaian sosial tinggi dengan persentase $2,56 \%$. Sehingga secara keseluruhan dapat disimpulkan bahwa semua anak mampu melakukan penyesuian sosial.

\section{Deskripsi Hasil Uji Hipotesis}

Beberapa cara untuk melakukan uji hipotesis yaitu dengan melihat persamaan regresi linear sederhana, hasil analisisnya dapat dilihat pada tabel berikut ini:

Tabel 8 Uji Regresi Linear Sederhana Untuk Mengetahui Persamaan Regresi, Uji Signifikansi dan Uji T

\begin{tabular}{|c|c|c|c|c|c|c|c|}
\hline \multicolumn{8}{|c|}{ Coefficients $^{a}$} \\
\hline & & \multicolumn{2}{|c|}{$\begin{array}{l}\text { Unstandardized } \\
\text { Coefficients }\end{array}$} & \multirow{2}{*}{\multicolumn{2}{|c|}{$\begin{array}{c}\begin{array}{c}\text { Standardized } \\
\text { Coefficients }\end{array} \\
\text { Beta } \\
\end{array}$}} & \multirow[b]{2}{*}{$\mathbf{t}$} & \multirow[b]{2}{*}{ Sig. } \\
\hline \multicolumn{2}{|c|}{ Model } & B & Std. Error & & & & \\
\hline \multirow[t]{2}{*}{1} & (Constant) & 49.739 & 18.987 & & & 2.620 & .013 \\
\hline & $\begin{array}{l}\text { Permainan Tradisional Petak } \\
\text { Umpet }\end{array}$ & .498 & .204 & & .373 & 2.444 & .019 \\
\hline
\end{tabular}

Dependent Variable: Penyesuaian Sosial Anak 
Secara umum rumus persamaan regresi linear sederhana adalah $\mathrm{Y}=\mathrm{a}+$ bX. a = angka konstan dari unstandardized coofficients diperoleh nilainya sebesar 49.739. Angka ini merupakan angka konstan yang mempunyai arti bahwa jika tidak ada permainan tradisional petak umpet $(\mathrm{X})$ maka nilai konsisten penyesuaian sosial anak (Y) adalah sebesar 49.739.b = angka koefisien regresi. Nilainya sebesar 0,498. Angka ini mengandung arti bahwa setiap penambahan $1 \%$ tingkat permainan tradisional petak umpet (X) maka penyesuaian sosial anak akan meningkat sebesar 0,498.Sehingga persamaan regresinya adalah $Y=49.739+$ $0,498 \mathrm{X}$ artinya permainan tradisional berpengaruh positif signifikan terhadap penyesuaian sosial anak.

Selain itu, pengujian hipotesis dapat dilihat dengan membandingkan nilai signifikansi dimana nilai signifikansi yang diperoleh sebesar 0,019 lebih kecil dari probabilitas 0,05 hal ini berarti ada pengaruh permainan tradisional petak umpet(X) terhadap penyesuaian sosial anak (Y). Sedangkan pengujian dengan membandingkan nilai $t$ hitung dengan $t$ tabel, diketahui nilai $t$ hitung sebesar 2,444 . Sedangkan untuk menentukan t tabel digunakan rumus: nilai 0,05/2=0,025, derajat kebebasan $(\mathrm{df})=\mathrm{n}-2=39-2=37$ maka nilai t tabel sebesar 2,026 maka dapat disimpulkan bahwa thitung 2,444 lebih besar dari t tabel 2,026 yang artinya ada pengaruh permainan tradisional $(\mathrm{X})$ terhadap penyesuaian sosial anak (X).

Selanjutnya untuk mengetahui besarnya pengaruh permainan tradisional petak umpet terhadap penyesuaian sosial anak berpedoman pada nilai $R$ Square atau R2 yang terdapat pada hasil perhitungan analisis regresi pada bagian model summary.

Tabel 9

Uji Regresi Untuk Menentukan Pengaruh Variabel X terhadap Variabel Y Model Summary

\begin{tabular}{lccccc}
\hline Model & R & R Square & Adjusted R Square & $\begin{array}{c}\text { Std. Error of the } \\
\text { Estimate }\end{array}$ \\
\hline 1 & $.373^{\mathrm{a}}$ & .139 & .116 & 5.252 \\
\hline Predictors: (Constant), Permainan Tradisional Petak Umpet & & \\
\hline
\end{tabular}

Hasil perhitungan besarnya pengaruh variabel $\mathrm{X}$ terhadap variabel $\mathrm{Y}$ diketahui nilai $R$ Square sebesar 0,139. Nilai ini mengandung arti bahwa pengaruh permainan tradisional petak umpet $(\mathrm{X})$ terhadap penyesuaian sosial anak (Y) adalah sebesar 0,139 atau $13,9 \%$ sedangkan sisanya sebesar $86,1 \%$ dipengaruhi oleh variabel lain yang tidak diteliti.

\section{PEMBAHASAN}

Permainan petak umpet sangat populer dibandingkan dengan permainan tradisional lainnya karena permainan ini sangat menyenangkan dan memiliki banyak manfaat diantaranya adalah anak menjadi lebih aktif, anak bisa bersosialisasi, anak belajar berhitung, anak menjadi kreatif, anak patuh pada aturan, belajar berdiskusi terhadap masalah yang muncul dalam permainan, dan 
juga mampu melatih sportivitas anak. Dari hasil penelitian ditemukan bahwa semua anak sudah melakukan permainan tradisional petak umpet hal ini dibuktikan dengan jawaban anak pada instrumen permainan tradisional petak umpet berada pada kategori sedang hal ini berarti 39 atau 100\% anak sudah melakukan permainan tradisional petak umpet.

Sementara penyesuaian sosial anak merupakan tingkah laku yang mendorong anak untuk menyesuaikan diri dengan orang lain dan kelompok sesuai dengan kesadaran dari dalam diri dan tuntutan lingkungan. Keberhasilan anak/individu dalam melakukan penyesuaian sosial antara lain kemampuan anak/individu dalam menjalin komunikasi dengan orang lain, dapat mengembangkan sikap sosial yang menyenangkan, seperti memberi bantuan kepada orang lain, memenuhi aturan, dan mampu mengaktualisasikan dirinya dalam kelompok, serta mampu bertindak sesuai dengan norma yang berlaku, toleransi, dan lain sebagainya. Selanjutnya, Hurlock (2002: 155-157) mengemukakan berbagai aspek dalam penyesuaian sosial, diantaranya: penampilan nyata, penyesuaian diri terhadap kelompok, sikap sosial, dan kepuasan pribadi. Pendapat Hurlock ini sesuai dengan hasil penelitian yang membuktikan bahwa anak-anak memiliki penyesuaian sosial yang berada pada kategori baik atau sedang yaitu sebanyak 38 anak atau 97,44\% dan 1 anak memiliki penyesuaian sosial yang sangat baik atau tinggi yaitu 2,56\% yang artinya bahwa semua anak mampu melakukan penyesuaian sosial.

Anak-anak sudah merasakan manfaat permainan tradisional petak umpet yaitu dapat meningkatkan penyesuaian sosial anak. Hasil penelitian juga menunjukan ada hubungan antara permainan tradisional petak umpet dengan penyesuaian sosial anak dimana diperoleh nilai signifikansi sebesar 0,171 lebih besar 0,05 yang artinya terdapat hubungan linear secara signifikan antara variabel permainan tradisional petak umpet $(\mathrm{X})$ dengan variabel penyesuaian sosial anak (Y).

Berdasarkan teori dan hasil penelitian diketahui bahwa permainan tradisional petak umpet berpengaruh terhadap penyesuaian sosial anak. Apabila anak tidak dapat atau tidak pernah melakukan permainan tradisional petak umpet maka penyesuaian sosial anak usia sekolah dasar kurang sedangkan anak yang sering melakukan permainan tradisional petak umpet penyesuian sosial anak semakin tinggi atau baik. Hal ini didukung dengan hasil penelitian dilihat dari hasil persamaan regresinya $\mathrm{Y}=49.739+0,498 \mathrm{X}$ artinya permainan tradisional berpengaruh positif signifikan terhadap penyesuaian sosial anak. Selain itu, pengujian hipotesis dilakukan dengan membandingkan nilai signifikansi dimana nilai signifikansi yang diperoleh sebesar 0,019 lebih kecil dari probabilitas 0,05 hal ini berarti ada pengaruh permainan tradisional petak umpet(X) terhadap penyesuaian sosial anak (Y). Sedangkan pengujian dengan membandingkan nilai t hitung dengan $t$ tabel, diketahui nilai t hitung sebesar 2,444 lebih besar t tabel sebesar 2,026 artinya ada pengaruh permainan tradisional (X) terhadap 
penyesuaian sosial anak (X). Selanjutnya dapat dilihat dari besarnya pengaruh permainan tradisional petak umpet terhadap penyesuaian sosial anak diketahui nilai $R$ Square sebesar 0,139. Nilai ini mengandung arti bahwa pengaruh permainan tradisional petak umpet $(\mathrm{X})$ terhadap penyesuaian sosial anak (Y) adalah sebesar 0,139 atau $13,9 \%$ sedangkan sisanya sebesar $86,1 \%$ dipengaruhi oleh variabel lain yang tidak diteliti. Disimpulkan bahwa "permainan tradisional petak umpet berpengaruh positif signifikan terhadap penyesuaian sosial anak usia sekolah dasar di RT 01 dan RT 02 dengan total pengaruh sebesar 13,9\%. Pengaruh positif signifikan ini bermakna semakin sering melakukan permainan tradisional maka akan semakin meningkatkan penyesuaian sosial anak atau semakin baik penyesuaian sosial anak. Sehingga hipotesis penelitian yang diterima adalah $\mathrm{Ha}$ yaitu "ada pengaruh yang positif signifikan permainan tradisional petak umpet terhadap penyesuaian sosial anak di RT 01 dan RT 02 Kelurahan Rewarangga Selatan Kecamatan Ende Timur”.

\section{SIMPULAN}

Hasil penelitian menunjukkan bahwa permainan tradisional petak umpet berada pada kategori sedang sebesar 39 atau 100\% sedangkan penyesuaian sosial berada pada kategori baik atau sedang yaitu sebanyak 38 anak atau 97,44\% dan 1 anak berada pada kategori sangat baik atau tinggi yaitu 2,56\% yang artinya bahwa semua anak mampu melakukan permainan tradisional petak umpet dan penyesuaian sosial dengan baik. Hasil persamaan regresi $\mathrm{Y}=49.739+0,498 \mathrm{X}$, nilai signifikansi yang diperoleh sebesar 0,019 lebih kecil dari probabilitas 0,05, nilai t hitung sebesar 2,444 lebih besar t tabel sebesar 2,026 dan nilai $R$ Square sebesar 0,139 atau 13,9\% sedangkan sisanya sebesar 86,1\% dipengaruhi oleh variabel lain yang tidak diteliti.Uji hipotesis menunjukkan hasil bahwa $\mathrm{Ha}$ diterima yaitu "ada pengaruh yang positif signifikan permainan tradisional petak umpet terhadap penyesuaian sosial anak di RT 01 dan RT 02 Kelurahan Rewarangga Selatan Kecamatan Ende Timur".

Hasil penelitian juga memberikan beberapa rekomendasi atau saran diantaranya: 1) anak harus mampu melakukan penyesuaian sosial dengan orangorang disekitarnya dengan cara bermain bersama dengan teman sebayanya, berkomunikasi, beradaptasi, karena dunia anak adalah dunia bermain,2) orangtuamembatasi anak dalam menggunakan alat permainan modern karena permainan yang baik adalah permainan yang dilakukan dengan orang lain sehingga anak bisa belajar untuk melakukan penyesuaian sosial. 3) lingkungan mendukung anak dengan tidak membatasi atau melarang anak saat bermain di lingkungan karena dengan anak bermain anak belajar untuk melakukan penyesuaian sosial. 


\section{DAFTAR PUSTAKA}

Agustin, N. (2017). Pengaruh Aktivitas Permainan Petak Umpet KataTerhadap Perkembangan Keaksaraan AnakKelompok B Di TK Bhakti KartikaPahayu Jaya Lampung BaratTahun Ajaran 2016/2017.Skripsi. Fakultas Keguruan Dan Ilmu Pendidikan. Bandar Lampung: Universitas Lampung.

Arikunto, S. (2013). Prosedur Penelitian Suatu Pendekatan Praktik. Jakarta: Rineka Cipta.

Hurlock, E., B. (2002). Psikologi Perkembangan Suatu Pendekatan Sepanjang Rentang Kehidupan. Edisi Kelima. Penerjemah: Istiwidayanti \& Soedjarwo. Jakarta: Erlangga.

Mulyani, N. (2016). Super Asyik Permainan Tradisional Anak Indonesia. Cetakan pertama. Yogyakarta: DIVA Press.

Sugiyono. (2010). Metode Penelitian Pendidikan Pendekatan Kuantitatif, Kualitatif, dan $R \& D$. Bandung: Alfabeta.

Wahyuni, I., S. (2009). Efektivitas Pemberian Permainan Tradisional Gobag Sodor Terhadap Penyesuaian Sosial Anak Sekolah Dasar Negeri Cakraningratan Surakarta. Skripsi Program Studi Psikologi. Fakultas Kedokteran. Surakarta: Universitas Sebelas Maret. 